\author{
๑I. I. Кулик, С. В. Хміль
}

Тернопільський національний медичний університет ілені I. Я. Горбачевсъкого МОЗ України

\title{
ЕФЕКТИВНІСТЬ КОНТРОЛЬОВАНОЇ ОВАРІАЛЬНОЇ СТИМУЛЯЦІї ЗА ДОВГИМ ПРОТОКОЛОМ У ЖІНОК З ЕНДОМЕТРІОЗ-АСОЦІЙОВАНИМ БЕЗПЛІДДЯМ
}

\begin{abstract}
Мета дослідження - проаналізувати ефективність контрольованої оваріальної стимуляції за довгим протоколом у жінок із безпліддям на фроні генітального ендометріозу.

Матеріали та методи. У дослідження увійшли 114 жінок віком від 21 до 40 років з ендометріоз-асоційованим безпліддям. Пацієнтки з ендометріоз-асоційованим безпліддям були поділені на підгрупи: 1a - з монолатеральними ендометріоїдними кістами; $1 b$ - з білатеральними ендометріоїдними кістами; $2 a$ - без рецидивних кіст у раніше прооперованому яєчнику; $2 b$ - 3 моно- або білатеральними кістами у раніше прооперованому яєчнику. До всіх пацієнток застосовували довгий протокол стимуляції з агоніст-ГнРГ. Оцінку аспірованих ооцитів проводили після денудації, перед процедурою ICSI.

Результати дослідження та їх обговорення. Найнижчу кількість фролікулів зафіксовано у пацієнток 2a і 2b груп, вона була вірогідно менша від результатів 1a (на 92,9 \%) i 1b (на 78,6 \%) груп. При аспірації отримували достовірно меншу кількість ооцитів у всіх дослідних групах стосовно групи порівняння. Кількість запліднених яйцеклітин була найвищою у групі порівняння, зокрема, вона перевищувала дані 1a i 1b груп на 25,0 \% відповідно, 2a і 2b груп - на 200,0 \%. У пацієнток із безпліддям на фоні ендометріозу вихід бластоцист був вірогідно меншим у 1b, 2a i 2b групах стосовно даних групи порівняння.

Висновки. Проведення контрольованої оваріальної стимуляції за довгим протоколом з використанням агоніст-ГнРГ у жінок з ендометріоз-асоційованим безпліддям вказує на низьку їі ефрективність у пацієнток із кістектомією в анамнезі стосовно жінок із трубно-перитонеальним фактором безпліддя. Встановлено найнижчу кількість досягнутих вагітностей у жінок із безпліддям на фроні кістектомії.
\end{abstract}

Ключові слова: безпліддя; ендометріоз; контрольована оваріальна стимуляція; ефективність.

\section{ЭФФЕКТИВНОСТЬ КОНТРОЛИРУЕМОЙ ОВАРИАЛЬНОЙ СТИМУЛЯЦИИ ПО ДЛИННОМУ ПРОТОКОЛУ У ЖЕНЩИН С ЭНДОМЕТРИОЗ-АССОЦИИРОВАННЫМ БЕСПЛОДИЕМ \\ Цель исследования - проанализировать эффективность контролируемой овариальной стимуляции с длинным про-} токолом у женщин с бесплодием на фроне генитального эндометриоза.

Материалы и методы. В исследование вошли 114 женщин в возрасте от 21 до 40 лет с эндометриоз-ассоциированным бесплодием. Пациентки с эндометриоз-ассоциированным бесплодием были разделены на подгруппы: 1a - с монолатеральными эндометриоидными кистами; $1 \mathrm{~b}$ - с билатеральными эндометриоидными кистами; $2 \mathrm{a}$ - без рецидивирующих кист в ранее прооперированном яичнике; $2 \mathrm{~b}$ - с моно- или билатеральными кистами в ранее прооперированном яичнике. Ко всем пациенткам применяли длинный протокол стимуляции с агонист-ГнРГ. Оценку аспирированных ооцитов проводили после денудации, перед процедурой ICSI.

Результаты исследования и их обсуждение. Самое низкое количество фоолликулов зафриксировали у пациенток $2 \mathrm{a}$ и 2b групп, которое было достоверно меньше результатов 1a (на 92,9%) и 1b (на 78,6 \%) групп. При аспирации получали достоверно меньшее количество ооцитов во всех исследуемых группах относительно группы сравнения. Количество оплодотворенных яйцеклеток было самым высоким в группе сравнения, в частности, оно превышало данные 1a и 1b групп на 25,0 \% соответственно, 2a и 2b групп - на 200,0 \%. У пациенток с бесплодием на фроне эндометриоза выход бластоцист был достоверно меньше в 1b, 2a и 2b группах относительно данных группы сравнения.

Выводы. Проведение контролируемой овариальной стимуляции по длинному протоколу с использованием агонист-ГнРГ у женщин с эндометриоз-ассоциированным бесплодием указывает на низкую ее эфорективность у пациенток с кистэктомией в анамнезе в отношении женщин с трубно-перитонеальным фактором бесплодия. Установлено самое низкое количество достигнутых беременностей у женщин с бесплодием на фоне кистэктомии.

Ключевые слова: бесплодие; эндометриоз; контролируемая овариальная стимуляция; эфроективность.

EFFICACY OF CONTROLLED LONG PROTOCOL OVARIAL STIMULATION IN WOMEN WITH ENDOMETRIOSISASSOCIATED INFERTILITY

The aim of the study - to analyze the effectiveness of controlled long protocol ovarian stimulation in women with infertility on the background of genitals endometriosis.

Materials and Methods. The study included 114 women aged 21 to 40 years with endometriosis-associated infertility. Patients with endometriosis-associated infertility were divided into subgroups: $1 \mathrm{a}$ - with monolateral endometrioid cysts; $1 \mathrm{~b}$ - with bilateral endometrioid cysts; $2 a$ - without recurrent cysts in the previously operated ovary; $2 b$ - with mono- or bilateral cysts on the previously operated ovary. All patients used a "long" protocol of agonist-GnRH stimulation. Evaluation of aspirated oocytes was performed after denudation, before the ICSI procedure.

Results and Discussion. The lowest number of follicles was recorded in patients of groups $2 \mathrm{a}$ and $2 \mathrm{~b}$, which was probably less than the results of groups $1 \mathrm{a}(92.9 \%)$ and $1 \mathrm{~b}(78.6 \%)$. During aspiration it was received significantly less oocytes in all experimental groups relative to the comparison group. The number of fertilized oocytes was the highest in the comparison group, in particular, it exceeded the data of groups $1 \mathrm{a}$ and $1 \mathrm{~b}$ by $25.0 \%$, respectively, $2 \mathrm{a}$ and $2 \mathrm{~b}$ groups by $200.0 \%$. In patients with 
infertility on the background of endometriosis, the yield of blastocysts was significantly lower in groups $1 \mathrm{~b}, 2 \mathrm{a}$ and $2 \mathrm{~b}$ relative to the data of the comparison group.

Conclusions. Long-term controlled ovarian stimulation using a $\mathrm{GnRH}$ agonist in women with endometriosis-associated infertility indicates a low efficacy in patients with a history of cystectomy vs in women with tubal-peritoneal infertility. The lowest number of pregnancies was found in women with endometriosis-associated infertility on the background of cystectomy.

Key words: infertility; endometriosis; controlled ovarian stimulation; efficacy.

ВСтУП. Генітальний ендометріоз - це хронічне, дисгормональне, запальне захворювання, що діагностують у 10-15 \% жінок репродуктивного віку [1]. Зв'язок між ендометріозом та безпліддям досліджений у науковій літературі, але певні причинно-наслідкові зв'язки все ще залишаються суперечливими [2]. У жінок із безпліддям поширеність ендометріозу становить 25-50 \%, тоді як у 30-50 \% жінок з ендометріозом виявляють безпліддя [3]. При цьому рівень фертильності жінок із нелікованим ендометріозом становить приблизно 2-10 \% [4]. Причини безпліддя у жінок з ендометріозом можуть варіювати від анатомічних порушень через спайковий процес та фріброз до ендокринних відхилень та імунологічних порушень [5], що клінічно проявляється різноманіттям симптомів [6].

Доведено, що медикаментозне та хірургічне лікування при безплідді, пов'язаному з ендометріозом, $\epsilon$ суперечливим, частково через їх помірний ефект, тому дані методи лікування слід застосовувати лише разом із допоміжними репродуктивними технологіями (ДРТ) [5]. В останні роки лікування ДРТ стало першим терапевтичним підходом до ендометріоз-асоційованого безпліддя [7]. Існують припущення, що жінки, яким проводили процедуру екстракорпорального запліднення (ЕКЗ), мають більший ризик рецидиву та прогресування ендометріозу внаслідок інвазивності процедури та гіперестрогенії. Рівень естрогенів у жінок, які перебувають у протоколі контрольованої оваріальної стимуляції (КОС), у 10 разів вищий, ніж у жінок у природному менструальному циклі, проте його показники різко знижуються після аспірації ооцитів, до того ж, зростає концентрація прогестерону, який призначають після трансвагінальної пункції як гормон другої фрази, з метою підтримання вагітності. Короткочасна гіперестрогенія частково нівелює симптоми ендометріозу та не сприяє його прогресуванню $[8,9]$. Дані ретроспективних досліджень вказують на те, що немає прямого зв'язку між розвитком та прогресуванням ендометріозу, показниками овуляторного резерву та програмами ДРТ [10-12].

МЕТА ДОСЛІДЖЕННЯ - проаналізувати ефективність контрольованої оваріальної стимуляції за довгим протоколом у жінок із безпліддям на фроні генітального ендометріозу.

МАТЕРІАЛИ ТА МЕТОДИ. У дослідження УвіЙшли 114 жінок віком від 21 до 40 років 3 ендометріоз-асоційованим безпліддям, яким проводили лікування у медичному центрі «Клініка професора С. Хміля». У групу порівняння увійшли 30 жінок із трубно-перитонеальним фрактором безпліддя, діагностованим за допомогою лапароскопії або ехосальпінгографії. У групу ретроспективного аналізу не включали пацієнток із ендометріозом III-IV ступенів, синдромом полікістозних яєчників; фріброміомою тіла матки (субмукозною, симптомною субсерозною чи інтрамуральною діаметром більше 2 см). Зовнішній генітальний ендометріоз був верифікований під час лапароскопії і підтверджений патогістологічним дослідженням (ендометріоїдна кіста яєчника чи ендометріоїдні кісти яєчників).

Пацієнтки з ендометріоз-асоційованим безпліддям були поділені на 2 групи. Групу 1 складали 54 жінки репродуктивного віку з неоперованими ендометріоїдними кістами діаметром до 4 см, групу 2 - 60 жінок, у яких в анамнезі було проведено хірургічне лікування ендометріоїдних кіст. Кожну з груп було поділено на 2 підгрупи: $1 \mathrm{a}(\mathrm{n}=26)$ - монолатеральні ендометріоїдні кісти; 1b $(n=28)$ - білатеральні ендометріоїдні кісти; 2a $(n=23)$ без рецидивних кіст у раніше прооперованому яєчнику; $2 b(n=37)$ - 3 моно- або білатеральними кістами у раніше прооперованому яєчнику. Наявність кіст підтверджувалася даними УзД та бімануальним обстеженням.

У всіх пацієнток використовували довгий протокол стимуляції з а-ГнРГ. Препарат «Декапептил-Депо» в дозі 3,75 мг триптореліну («Decapeptyl», Ferring, Німеччина) вводили внутрішньом' язово на 19-21 день попереднього менструального циклу. Після досягнення супресії гіпосріза (підтвердженої даними ультразвукового та гормонального дослідження) пацієнткам проводили стимуляцію суперовуляції. Як індуктор стимуляції росту фролікулів використовували препарат пролонгованої дії коліфолітропін альсра «Елонва» та рекомбінантний ФСГ «Пурегон». Елонву вводили в перший день стимуляції, «Пурегон» - на 8-й день стимуляції. Дозу р-ФСГ підбирали індивідуально з урахуванням гормональних показників, віку пацієнток та відповіді яєчників на стимуляцію. Як тригер овуляції використовували хоріонічний гонадотропін («Хоріомон» або «Прегніл»), даний препарат призначали пацієнтам у випадку двох і більше фролікулів діаметром 18-19 мм. У день введення а-ГнРГ та впродовж всієї стимуляції проводили ультразвуковий контроль із застосуванням трансвагінального датчика з подальшим зазначенням діаметра фолікулів та товщини ендометрія.

Забір ооцитів проводили через 36 год після введення тригера овуляції, запліднення яйцеклітин та культивування ембріонів із подальшою імовірною вітрифрікацією або трансорером у порожнину матки на 5-6-ту доби (стадія бластоцисти) здійснювали в умовах ембріологічної лабораторії.

Оцінку аспірованих ооцитів проводили після денудації, перед процедурою ICSI. Оцінювали генетичну зрілість яйцеклітин (GV, MI, MII). Опис морфометричних параметрів ооцитів проводили за допомогою таких показників: оцінка прозорої оболонки (zona pellucida), її зовнішній вигляд, структура та товщина, зміни у величині та формі самого ооцита, якість цитоплазми (наявність цитоплазматичних включень, вакуолізація, цитоплазматична зернистість), характеристика перивітелінового простору, стан полярного тіла.

Результати запліднення оцінювали через 16-19 год після процедури ICSI - співвідношенням зигот із двома 
пронуклеусами до загальної кількості імовірних зигот. Якість дроблення ембріонів описували наявністю фрагментації цитоплазми та кількості і симетрії бластомерів. Вихід бластоцист оцінювали на 5-6-ту доби. Якісну характеристику ембріонів на стадії бластоцисти проводили за системою Gardner [13]. Після перенесення ембріонів у порожнину матки пацієнтки отримували підтримувальну терапію до отримання результату на $\beta$-ХГЛ. При позитивному результаті тесту на вагітність підтримку продовжували до 10-12 тижнів.

Статистичний аналіз результатів дослідження здійснювали за допомогою комп'ютерного забезпечення 3 використанням програм «Microsoft Office Excell» та «Statistica 7.0». Вибір методу аналізу одержаних даних базувався на кількості груп, які включались в обстеження, правильності розподілу величин у них, а також рівностях дисперсій. При неправильному розподілі величин їх представляли у вигляді Me (Q25; Q75) (медіани та Q25 і Q75 квартилів).

РЕЗУЛЬТАТИ ДОСЛІДЖЕННЯ ТА ЇХ ОБГОВОРЕННЯ. Серед пацієнток з ендометріоз-асоційованим безпліддям тривалість стимуляції у пацієнток групи порівняння становила $10,5(10,0 ; 10,8)$ дня, що було вірогідно меншим стосовно тривалості індукції суперовуляції в пацієнток 1b, 2a i 2b груп $(p<0,05)$.

Сумарна доза рекомбінантного ФСГ у пацієнток дослідних груп була вірогідно вищою стосовно групи порівняння. При цьому найвищі значення р-ФСГ «Пурегон» МО, введеного з 8-го дня стимуляції суперовуляції, зафріксовано в 2b групі (1250 (1100; 1375)), які вірогідно перевищували дозу рекомбінантного ФСГ в 1а (на 22,2 \%) i 1b (на 15,8 \%) групах (рис. 1).

У результаті контрольованої оваріальної стимуляції за довгим протоколом встановлено, що середнє число фолікулів пацієнток різних дослідних груп вірогідно різнилося при проведенні аналізу рангових варіацій Краскела-Уолліса, при цьому показники дослідних груп були статистично значимо нижчі стосовно даних групи порівняння. Найнижчу кількість фролікулів зафіксовано у пацієнток 2a і 2b груп, вона була вірогідно менша від результатів 1a (на 92,9 \%) і 1b (на 78,6 \%) груп. При аспірації отримували достовірно меншу кількість ооцитів у всіх дослідних групах стосовно групи порівняння, 30крема у 1а групі на 13,6 \%, відповідно, у 1 b - на 25,0 \%, у 2 a - на $108,3 \%$ і у 2 b групі - на $150,0 \%$. При цьому відсоток зрілих ооцитів різних дослідних груп вірогідно різнився при проведенні аналізу рангових варіацій Краскела-Уолліса. Кількість запліднених яйцеклітин була найвищою у групі порівняння, зокрема, вона перевищувала дані $1 \mathrm{a}$ i 1b груп на 25,0 \% відповідно, 2a i 2b груп - на 200,0 \%. У пацієнток із безпліддям на фоні ендометріозу вихід бластоцист був вірогідно меншим у 1 b, 2a i 2b групах стосовно даних групи порівняння, при цьому в жінок з монолатеральними кістами вихід бластоцист був статистично значимо вищий стосовно пацієнток після кістектомії (табл. 1). Слід також зазначити, що відсутність морули чи/або бластоцисти на день переносу привела до виведення з протоколу 1 пацієнтки 2a групи і 3 пацієнток 2b групи.

При аналізі числа ембріонів високого класу встановлено, що у групі порівняння переважали жінки 32 (40,0 \%) і 3 (43,3 \%) ембріонами високого класу; відповідно, в 1а групі також із 2 (30,8 \%) і 3 (38,5 \%) ембріонами високого класу; у 1 b - 31 (50,0 \%) і 2 (28,6 \%) ембріонами високого класу; у 2а - 31 ембріоном високого класу (43,5 \%) або ж без жодного (34,8 \%) та у 2 b групі у переважній більшості жінок не виявлено ембріонів високого класу (45,9\%) або ж лише 1 (32,4 \%) (рис. 2).

Про результативність методу екстракорпорального запліднення у жінок із діагностованим безпліддям на фоні ендометріозу свідчить частота настання вагітності у стимульованих циклах. Встановлено, що кількість досягнутих вагітностей у жінок із безпліддям на фроні неоперованих монолатеральних кіст становила 7, відповідно, на фроні неоперованих білатеральних кіст - 7, на фоні кістектомії без рецидивів - 4, на фроні кістектомії з діагностованими рецидивами - 6, що у відсотковому співвідношенні було найнижчим показником (рис. 3).

Систематичний огляд та метааналіз Hamdan M. і співавт. засвідчив меншу кількість ооцитів та частішу

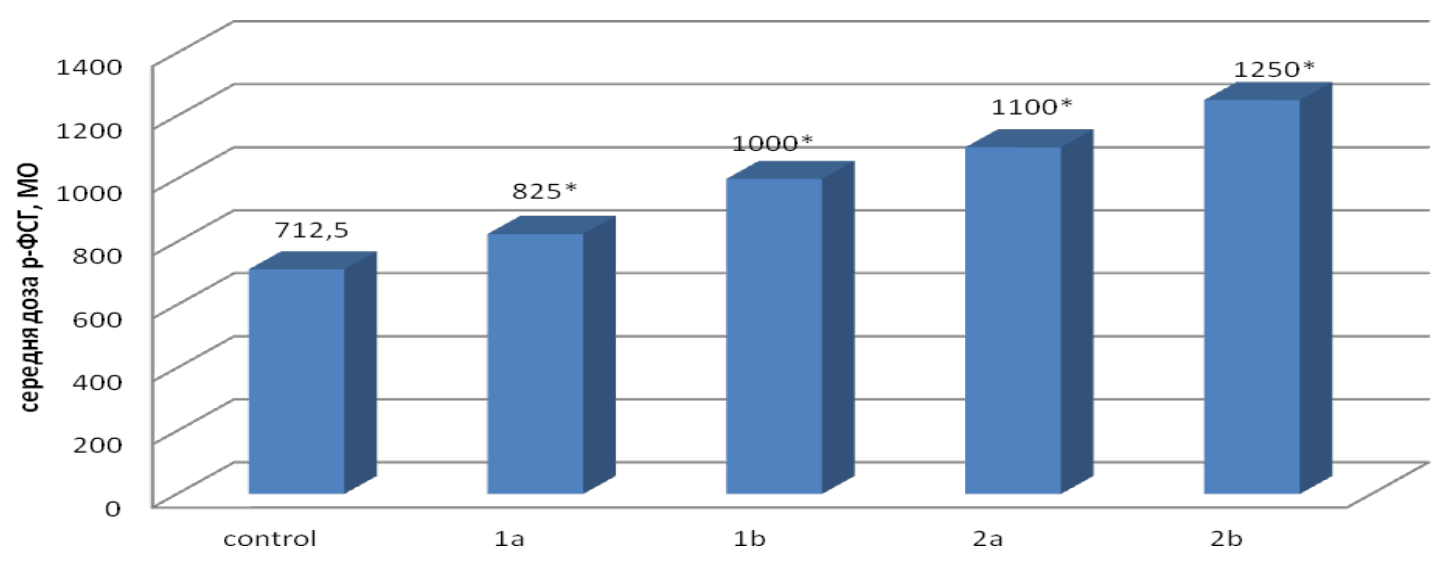

Рис. 1. Середня доза р-ФСГ «Пурегон» МО, введеного з 8-го дня стимуляції суперовуляції пацієнткам із безпліддям на фоноі ендометріозу.

Примітки:

1. Критерій Краскела-Уолліса в межах груп, включених у дослідження - 87,92; p<0,001.

2. $\mathbf{p}<0,05$ для коефіцієнта Краскела-Уолліса при попарному порівнянні груп 1a-1b, 1a-2a, 1a-2b, 1b-2b.

3. * - статистично вірогідні результати стосовно контролю. 
Таблиця 1. Параметри індукції суперовуляції у жінок із безпліддям на фоні ендометріозу

\begin{tabular}{|c|c|c|c|c|c|c|}
\hline Кількість & $\begin{array}{c}\text { Група } \\
\text { порівняння } \\
(n=30) \\
\end{array}$ & $\begin{array}{c}\text { 1a }(\mathrm{n}=26) \\
\text { Неоперовані } \\
\text { монолатеральні }\end{array}$ & $\begin{array}{c}\text { 1b (n=28) } \\
\text { Неоперовані } \\
\text { білатеральні }\end{array}$ & $\begin{array}{c}2 a(n=23) \\
\text { Оперовані без } \\
\text { рецидивів }\end{array}$ & $\begin{array}{c}\text { 2b (n=37) } \\
\text { Оперовані } 3 \\
\text { рецидивами }\end{array}$ & $\begin{array}{c}\text { Критерій } \\
\text { Краскела- } \\
\text { Уолліса } \\
\end{array}$ \\
\hline Фолікулів & $\begin{array}{c}15,0 \\
(16,5 ; 18,0)\end{array}$ & $\begin{array}{c}13,5 \\
(10,8 ; 14,8) \#\end{array}$ & $\begin{array}{c}12,5 \\
(10,0 ; 15,0) \#\end{array}$ & $\begin{array}{c}7,0 \\
(6,0 ; 9,0) \#\end{array}$ & $\begin{array}{c}7,0 \\
(5,0 ; 10,0) \#\end{array}$ & $\begin{array}{l}H=84,95 \\
p<0,001^{*}\end{array}$ \\
\hline $\begin{array}{l}\text { Отриманих } \\
\text { ооцитів }\end{array}$ & $\begin{array}{c}12,5 \\
(11,0 ; 15,0)\end{array}$ & $\begin{array}{c}11,0 \\
(9,3 ; 12,0) \#\end{array}$ & $\begin{array}{c}10,0 \\
(8,8 ; 12,0) \#\end{array}$ & $\begin{array}{c}6,0 \\
(4,5 ; 8,0) \#\end{array}$ & $\begin{array}{c}5,0 \\
(3,0 ; 7,0) \#\end{array}$ & $\begin{array}{l}H=77,82 \\
p<0,001^{*}\end{array}$ \\
\hline Зрілих ооцитів & $\begin{array}{c}10,0 \\
(10,5 ; 13,0)\end{array}$ & $\begin{array}{c}9,0 \\
(8,0 ; 11,0) \#\end{array}$ & $\begin{array}{c}8,0 \\
(6,8 ; 10,0) \#\end{array}$ & $\begin{array}{c}4,0 \\
(3,5 ; 7,0) \#\end{array}$ & $\begin{array}{c}4,0 \\
(3,0 ; 5,0) \#\end{array}$ & $\begin{array}{l}H=70,03 \\
p<0,001^{*}\end{array}$ \\
\hline $\begin{array}{l}\text { Усіх запліднених } \\
\text { клітин }\end{array}$ & $\begin{array}{c}9,0 \\
(7,3 ; 10,0)\end{array}$ & $\begin{array}{c}6,0 \\
(5,0 ; 8,0) \#\end{array}$ & $\begin{array}{c}6,0 \\
(4,8 ; 7,3) \#\end{array}$ & $\begin{array}{c}3,0 \\
(2,0 ; 4,5) \#\end{array}$ & $\begin{array}{c}3,0 \\
(2,0 ; 4,0) \#\end{array}$ & $\begin{array}{l}H=77,76 \\
p<0,001^{*}\end{array}$ \\
\hline $\begin{array}{l}\text { Вихід } \\
\text { бластоцист }\end{array}$ & $\begin{array}{c}4,0 \\
(3,0 ; 5,0)\end{array}$ & $\begin{array}{c}3,0 \\
(2,0 ; 4,0)\end{array}$ & $\begin{array}{c}2,0 \\
(1,8 ; 3,0) \#\end{array}$ & $\begin{array}{c}1,5 \\
(1,0 ; 2,0) \#\end{array}$ & $\begin{array}{c}1,0 \\
(1,0 ; 2,0) \#\end{array}$ & $\begin{array}{l}H=61,20 ; \\
p<0,001^{*}\end{array}$ \\
\hline
\end{tabular}

Примітки:

1. * - статистично достовірні результати в межах дослідних груп.

2. \# - статистично вірогідні результати стосовно контролю.

3. Кількість фролікулів: p<0,05 для коефіцієнта Краскела-Уолліса при попарному порівнянні груп 1a-2a, 1a-2b, 1b-2a, $1 \mathrm{~b}-2 \mathrm{~b}$.

4. Кількість отриманих ооцитів: p<0,05 для коефріцієнта Краскела-Уолліса при попарному порівнянні груп 1a-2a, 1a-2b, $1 b-2 a, 1 b-2 b$.

5. Кількість зрілих ооцитів: p<0,05 для коефіцієнта Краскела-Уолліса при попарному порівнянні груп 1a-2a, 1a-2b, $1 \mathrm{~b}-2 \mathrm{a}, 1 \mathrm{~b}-2 \mathrm{~b}$.

6. Кількість усіх запліднених клітин: p<0,05 для коефіцієнта Краскела-Уолліса при попарному порівнянні груп 1а-2а, $1 \mathrm{a}-2 \mathrm{~b}, 1 \mathrm{~b}-2 \mathrm{a}, 1 \mathrm{~b}-2 \mathrm{~b}$.

7. Вихід бластоцист: p<0,05 для коефіцієнта Краскела-Уолліса при попарному порівнянні груп 1a-2a, 1a-2b, 1b-2b.

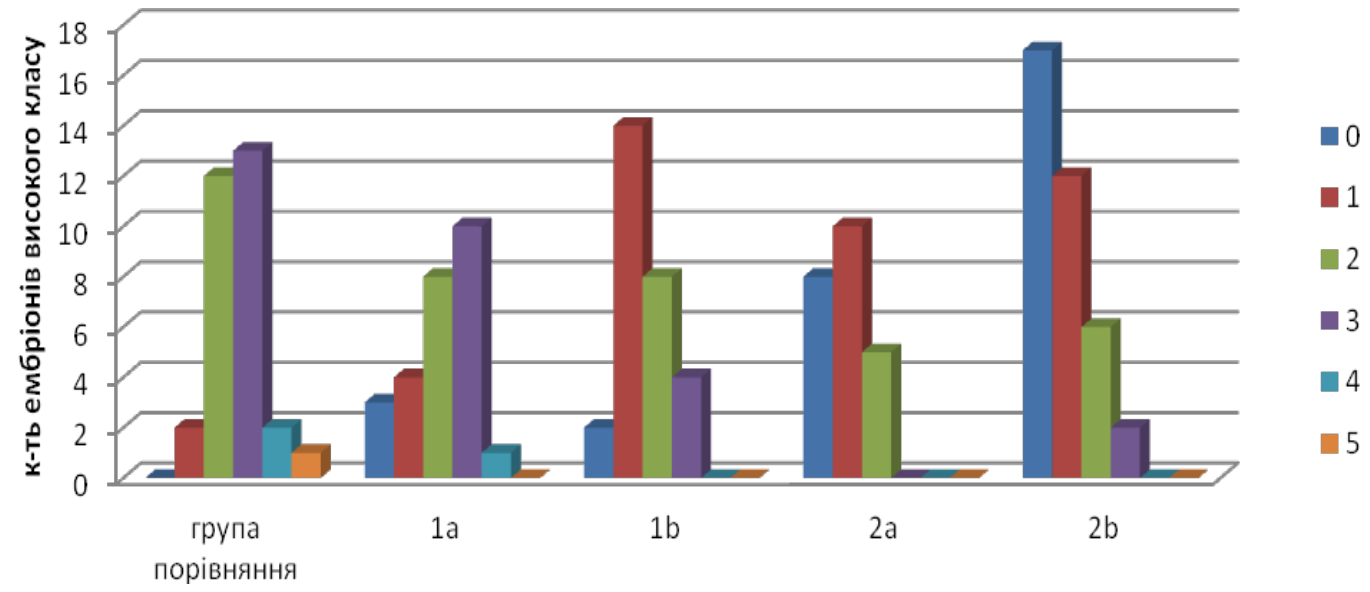

Рис. 2. Кількість ембріонів високого класу у жінок із безпліддям на фоні ендометріозу залежно від типу лікування.

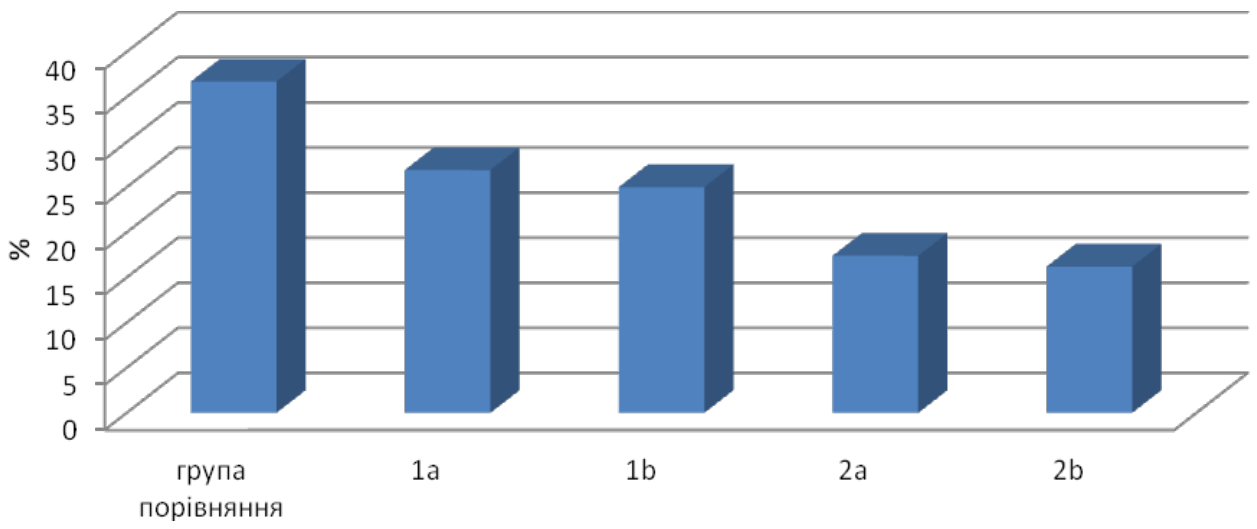

Рис. 3. Відсоток вагітностей при екстракорпоральному заплідненні у досліджуваних групах жінок з ендометріозом. 
відсутність ембріонів високого класу при екстракорпоральному заплідненні у жінок з ендометріоз-асоційованим безпліддям стосовно жінок з іншими фракторами безпліддя [14], що зіставно з нашими результатами. Surrey E. S. разом з колегами продемонстрував ефективність двомісячного курсу терапії агоніст-ГнРГ [15]. Ren J. та співавт. показали вищу кількість досягнутих вагітностей завдяки довготривалому зниженню регулювання гіпосріза у жінок без ендометріозу, що можна застосовувати у пацієнток 3 ендометріозом [16]. Khan K. N. та співавт. зазначають, що тривала супресія гіпофріза знижує щільність мікросудин ендометріотичних вогнищ, зменшуючи приплив крові до вогнищ [17]. Результати нашого дослідження також показали низьку ефективність КОС за довгим протоколом у жінок із безпліддям на тлі ендометріозу, яким попередньо проводили хірургічне лікування (кістектомію).

\section{СПИСОК ЛІТЕРАТУРИ}

1. Macer M. L. Endometriosis and infertility: a review of the pathogenesis and treatment of endometriosis-associated infertility / M. L. Macer, H. S. Taylor // Obstet. Gynecol. Clin. North Am. - 2012. - Vol. 39 (4). - P. 535-549.

2. Ziegler de D. Endometriosis and infertility: pathophysiology and management / D. de Ziegler, B. Borghese, C. Chapron // Lancet. - 2010. - Vol. 376 (9742). - P. 730-738.

3. High prevalence of endometriosis in infertile women with normal ovulation and normospermic partners / C. Meuleman, B. Vandenabeele, S. Fieuws [et al.] // Fertil. Steril. - 2009. Vol. 92 (1). - P. 68-74.

4. Endometriosis and infertility: a committee opinion / Practice Committee of the American Society for Reproductive Medicine // Fertil. Steril. - 2012. - Vol. 98 (3). - P. 591-8.

5. Tanbo T. Endometriosis-associated infertility: aspects of pathophysiological mechanisms and treatment options / T. Tanbo, P. Fedorcsak // Acta Obstet. Gynecol. Scand. - 2017. - Vol. 96 (6). - P. 659-667.

6. Gupta S. Endometriosis: A Comprehensive Update / S. Gupta, A. Harlev, A. Agarwal. - Springer International Publishing: Cham, Switzerland, 2015.

7. ESHRE guideline: management of women with endometriosis / G. A. Dunselman, N. Vermeulen, C. Becker [et al.] // Hum. Reprod. - 2014. - Vol. 29. - P. 400-412.

8. Estrogen-progestins and progestins for the management of endometriosis / P. Vercellini, L. Buggio, N. Berlanda [et al.] // Fertil. Steril. - 2016. - Vol. 106 (7). - P. 1552-1571.

9. Treatment of endometriosis-associated pain with elagolix, an oral GnRH antagonist / H. S. Taylor, L. C. Giudice, B. A. Lessey [et al.] // N. Engl. J. Med. - 2017. - Vol. 377 (1). - P. 28-40.
Висновок. Проведення контрольованої оваріальної стимуляції за довгим протоколом із використанням агоніст-ГнРГ у жінок з ендометріоз-асоційованим безпліддям вказує на низьку її ефективність у пацієнток із кістектомією в анамнезі (вірогідно нижча кількість фолікулів та ооцитів, кількість усіх запліднених клітин та вихід бластоцист) стосовно жінок із трубно-перитонеальним фрактором безпліддя.

Встановлено найнижчу кількість досягнутих вагітностей у жінок із безпліддям на фоні кістектомії (без рецидивів $-17,4 \%$, із діагностованими рецидивами - 16,2 \%).

ПЕРСПЕКТИВИ ПОДАЛЬШИХ ДОСЛІДЖЕНЬ. Розроблення та впровадження модифікованої схеми контрольованої оваріальної стимуляції з використанням прегравідарної терапії для покращення оваріальної відповіді та якості яйцеклітин у жінок із безпліддям на фроні генітального ендометріозу.

10. Control-matched surgical evaluation of endometriosis progression after IVF: a retrospective cohort study / P. Crochet, R. Lathi, M. Dahan [et al.] // Minerva Ginecol. - 2016. - Vol. 68 (5). - P. 481-486.

11. Stilley J. A. W. Cellular and molecular basis for endometriosis associated infertility / J. A. W. Stilley, J. A. Birt, K. L. Sharpe-Timms // Cell Tissue Res. - 2012. - Vol. 349 (3). - P. 849-862.

12. Age, independent from ovarian reserve status, is the main prognostic factor in natural cycle in vitro fertilization / I. Gonzalez Foruria, J. Penarrubia, A. Borras [et al.] // Fertil. Steril. - 2016. - Vol. 106 (2). - P. 342-347.

13. Данкович Н. А. Причины и фрормы бесплодия. Современные возможности диагностики и лечения / Н. А. Данкович, В. Н. Воробей-Виховская // Здоровье женщины. - 2013. № 3. - С. 192-197.

14. The impact of endometrioma on IVF/ICSI outcomes: A systematic review and meta-analysis / M. Hamdan, G. Dunselman, T. C. Li, Y. Cheong // Hum. Reprod. Update. 2015. - Vol. 21 (6). - P. 809-825.

15. Menotropin stimulation after prolonged gonadotropin releasing hormone agonist pretreatment for in vitro fertilization in patients with endometriosis / K. Nakamura, M. Oosawa, I. Kondou [et al.] // J. Assist. Reprod. Genet. - 1992. - Vol. 9 (2). - P. 113-117.

16. Does prolonged pituitary down-regulation with gonadotropin-releasing hormone agonist improve the live-birth rate in in vitro fertilization treatment? / J. Ren, A. Sha, D. Han [et al.] // Fertil. Steril. - 2014. - Vol. 102 (1). - P. 75-81.

17. Changes in tissue inflammation, angiogenesis and apoptosis in endometriosis, adenomyosis and uterine myoma after GnRH agonist therapy / K. N. Khan, M. Kitajima, K. Hiraki [et al.] // Hum. Reprod. - 2010. - Vol. 25 (3). - P. 642-653. 


\section{REFERENCES}

1. Macer, M.L., \& Taylor, H.S. (2012). Endometriosis and infertility: a review of the pathogenesis and treatment of endometriosis-associated infertility. Obstet. Gynecol. Clin. North Am., 39 (4), 535-549. DOI:10.1016/j.ogc.2012.10.002.

2. Ziegler, de D., Borghese, B., \& Chapron, C. (2010). Endometriosis and infertility: pathophysiology and management. Lancet, 376 (9742), 730-738. DOI: 10.1016/S01406736(10)60490-4.

3. Meuleman, C., Vandenabeele, B., Fieuws, S., Spiessens, C., Timmerman, D., \& D'Hooghe, T. (2009). High prevalence of endometriosis in infertile women with normal ovulation and normospermic partners. Fertil. Steril., 92 (1), 68-74. DOI: 10.1016/j. fertnstert.2008.04.056

4. Practice Committee of the American Society for Reproductive Medicine (2012). Endometriosis and infertility: a committee opinion. Fertil. Steril., 98 (3), 591-8. DOI: 10.1016/j. fertnstert.2012.05.031.

5. Tanbo, T., \& Fedorcsak, P. (2017). Endometriosis-associated infertility: aspects of pathophysiological mechanisms and treatment options. Acta Obstet. Gynecol. Scand., 96 (6) 659-667. DOI: 10.1111/aogs.13082.

6. Gupta, S., Harlev, A., \& Agarwal, A. (2015). Endometriosis: a comprehensive update. Springer International Publishing: Cham, Switzerland.

7. Dunselman, G.A., Vermeulen, N., Becker, C., CalhazJorge, C., D'Hooghe, T., De Bie, B., ..., \& Nelen, W. (2014). ESHRE guideline: management of women with endometriosis. Hum. Reprod., 29, 400-412. DOI: 10.1093/humrep/det457.

8. Vercellini, P., Buggio, L., Berlanda, N., Barbara, G., Somigliana, E., \& Bosari, S. (2016). Estrogen-progestins and progestins for the management of endometriosis. Fertil. Steril., 106 (7), 1552-1571. DOI: 10.1016/j.fertnstert.2016.10.022.

9. Taylor, H.S., Giudice, L.C., Lessey, B.A., Abrao, M.S. Kotarski, J., Archer, D.F., ..., \& Chwalisz, K. (2017). Treatment of endometriosis-associated pain with elagolix, an oral $\mathrm{GnRH}$ antagonist. N. Engl. J. Med., 377 (1), 28-40. DOI: 10.1056/ NEJMoa1700089.
10. Crochet, P., Lathi, R., Dahan, M., Ocampo, J., Nutis, M., \& Nezhat, C.R. (2016). Control-matched surgical evaluation of endometriosis progression after IVF: a retrospective cohort study. Minerva Ginecol., 68 (5), 481-486.

11. Stilley, J.A.W., Birt, J.A., \& Sharpe-Timms, K.L. (2012). Cellular and molecular basis for endometriosis associated infertility. Cell Tissue Res., 349 (3), 849-862. DOI: 10.1007/ s00441-011-1309-0.

12. Gonzalez Foruria, I., Penarrubia, J., Borras, A. Manau, D., Casals, G., Peralta, S., ..., \& Fàbregues, F. (2016). Age, independent from ovarian reserve status, is the main prognostic factor in natural cycle in vitro fertilization. Fertil. Steril., 106 (2), 342-347. DOI: 10.1016/j.fertnstert.2016.04.007.

13. Dankovich, N.A., \& Vorobey-Vikhovskaya, V.N. (2013). Prichiny i formy besplodiya. Sovremennyye vozmozhnosti diagnostiki i lecheniya [Causes and forms of infertility. Modern possibilities of diagnostics and treatment]. Zdorovye zhenshchiny - Women's Health, 3, 192-197 [in Russian].

14. Hamdan, M., Dunselman, G., Li, T.C., \& Cheong, Y. (2015). The impact of endometrioma on IVF/ICSI outcomes: A systematic review and meta-analysis. Hum. Reprod. Update., 21 (6), 809-825. DOI: 10.1093/humupd/dmv035.

15. Nakamura, K., Oosawa, M., Kondou, I., Inagaki, S., Shibata, H., Narita, O., ..., \& Tomoda, Y. (1992). Menotropin stimulation after prolonged gonadotropin releasing hormone agonist pretreatment for in vitro fertilization in patients with endometriosis. J. Assist. Reprod. Genet., 9 (2), 113-117. DOI: 10.1007/BF01203749.

16. Ren, J., Sha, A., Han, D., Li, P., Geng, J., Ma, C. (2014). Does prolonged pituitary down-regulation with gonadotropinreleasing hormone agonist improve the live-birth rate in in vitro fertilization treatment? Fertil. Steril., 102 (1), 75-81. DOI: 10.1016/j.fertnstert.2014.03.030.

17. Khan, K.N., Kitajima, M., Hiraki, K., Fujishita, A., Sekine, I., Ishimaru, T., \& Masuzaki, H. (2010). Changes in tissue inflammation, angiogenesis and apoptosis in endometriosis, adenomyosis and uterine myoma after GnRH agonist therapy. Hum. Reprod., 25 (3), 642-653. DOI: 10.1093/humrep/dep437.

Отримано 18.09.20 Прийнято до друку 20.10.20 Електронна адреса для листування: kulyk iryna1@ukr.net 